\title{
PERBANDINGAN KADAR KOLESTEROL HIGH DENSITY LIPOPROTEIN DARAH PADA WANITA OBES DAN NON OBES
}

\author{
${ }^{1}$ Hanif B. S. Gani \\ ${ }^{2}$ Djon Wongkar \\ ${ }^{2}$ Shane H. R Ticoalu
}

\author{
${ }^{1}$ Kandidat Skripsi Fakultas Kedokteran Universitas Sam Ratulangi Manado \\ ${ }^{2}$ Bagian Anatomi Histologi Fakultas Kedokteran Universitas Sam Ratulangi Manado \\ Email: hanifbenazir@yahoo.com
}

\begin{abstract}
In general, obesity is associated with a decrease of blood HDL-cholesterol level and an increase of serum triglyceride level. In obese people, the triglyceride is deposited in the subcutaneous layer of the skin. This triglyceride plays an important role in the formation of VLDL and LDL-cholesterol in the liver which will be released into the blood. This was an observational study with a cross-sectional design. Samples were 22 obese female students and 22 non-obese female students of Faculty of Medicine, University of Sam Ratulangi Manado aged 18-22 years. The results showed that the mean HDL-cholesterol levels in obese females was $57.64 \mathrm{mg} / \mathrm{dL}$, meanwhile of the non-obese females was $61.77 \mathrm{mg} / \mathrm{dL}$. Albeit, the statistical analysis showed no significant difference between the HDL-cholesterol levels of obese and non-obese females ( $P$-value 0.974). Conclusion: There was no significant difference between the HDL-cholesterol levels of obese females and non obese females.
\end{abstract}

Keywords: HDL-cholesterol levels, females, obese, non obese

\begin{abstract}
Abstrak: Obesitas berhubungan dengan penurunan kadar kolesterol HDL darah dan peningkatan kadar serum trigliserida. ${ }^{3}$ Pada individu obes, trigliserida disimpan pada jaringan subkutan. Trigliserida itu merupakan bahan utama pembentukan VLDL dan LDL di hati yang akan dilepaskan ke dalam darah. Penelitian ini bersifat observasional dengan menggunakan cross-sectional design. Sampel penelitian terdiri dari 22 mahasiswi Fakultas Kedokteran Universitas Sam Ratulangi yang obes dan 22 mahasiswi yang non-obes. Hasil penelitian memperlihatkan bahwa rerata kadar kolesterol HDL pada sampel yang obes 57,64 mg/dL dan pada yang non-obes $61,77 \mathrm{mg} / \mathrm{dL}$. Uji statistik memperlihatkan tidak terdapat perbedaan bermakna antara kadar kolesterol HDL darah pada wanita yang obes dan yang non-obes $(P=$ 0,974). Simpulan: Tidak terdapat perbedaan bermakna antara kadar kolesterol HDL darah pada wanita obes dan wanita non-obes.
\end{abstract}

Kata kunci: kadar kolestrol HDL, wanita, obes, non-obes.

High Density Lipoprotein (HDL) merupakan kolesterol darah yang disintesis dan disekresi dari hati dan usus. ${ }^{1}$ Orang dengan Indeks Massa Tubuh (IMT) normal memiliki kadar kolesterol HDL darah antara 35$45 \mathrm{~g} / \mathrm{dL}$. Namun berbeda dengan obesitas. Obesitas berhubungan dengan penurunan kadar kolesterol HDL darah dan peningkatan kadar serum trigliserida. ${ }^{2}$
Orang gemuk memiliki kadar trigliserida yang tinggi dan disimpan di bawah kulit. Simpanan trigliserida itu merupakan bahan utama pembentukan Very Low Density Lipoprotein (VLDL) dan Low Density Lipoprotein (LDL) di hati dan akan masuk ke dalam darah. ${ }^{3}$

Rendahnya kadar kolesterol HDL darah merupakan faktor risiko yang kuat terhadap 
penyakit kardiovaskuler serta sindrom metabolik. Di United State of America, terjadinya peningkatan prevalensi sindrom metabolik disebabkan oleh peningkatan kejadian obesitas. Prevalensi obesitas pada anak dan dewasa di Amerika Serikat dan di Negara-negara maju lainnya sangat meningkat dan bertambah lebih dari 30\% selama dekade terakhir. Sekitar $64 \%$ orang dewasa di Amerika Serikat mengalami overweight dan 33\% mengalami obesitas. ${ }^{4}$ Prevalensi sindrom metabolik pada populasi usia $>20$ tahun sebesar $25 \%$ dan pada usia $>50$ tahun sebesar $45 \%$. Hal ini berkembang dengan peningkatan prevalensi obesitas yang terjadi pada populasi Asia, termasuk Indonesia. Penelitian Soegondo (2004) melaporkan prevalensi sindrom metabolik sebesar 13,13\% dan menunjukkan bahwa kriteria Indeks Massa Tubuh (IMT) obesitas $>25 \mathrm{~kg} / \mathrm{m} 2$ lebih cocok untuk diterapkan di Indonesia. ${ }^{5}$ Menurut World Health Organization (WHO) pada tahun 2005 sekitar 1,6 miliar orang dewasa di atas usia 15 tahun kelebihan berat badan, juga terdapat 400 juta orang dewasa menderita obesitas dan 20 juta anak di bawah usia 5 tahun kelebihan berat badan. ${ }^{6}$ Selain itu Riset Kesehatan Dasar (Riskesdas) Kementrian Kesehatan tahun 2010 lalu menemukan kasus kelebihan berat badan atau obesitas di Jakarta mencapai angka 28,5\%, atau tiga kali lebih tinggi daripada kasus kurang gizi. Sedangkan di Sulawesi Utara kasus obesitas mencapai 37,1\%. Riset ini menyimpulkan bahwa, wanita memiliki masalah obesitas yang lebih tinggi dibandingkan pria. Pada tahun 2010, pria mengalami obesitas berada pada tingkat $7,80 \%$ dan wanita berada pada angka $15,50 \%{ }^{7}$

Berdasarkan pembahasan-pembahasan tersebut maka penulis tertarik untuk membandingkan kadar kolesterol HDL darah pada Mahasiswi Fakultas Kedokteran UNSRAT yang obes dan non obes.

\section{METODE}

Jenis penelitian yang digunakan dalam penelitian ini yaitu penelitian observasional dengan menggunakan desain penelitian cross sectional. Penelitian dilakukan pada bulan November 2012. Lokasi penelitian dilaksanakan di Fakultas Kedokteran UNSRAT Manado dengan menggunakan teknik purposive sampling. Populasi berjumlah 587 orang terdiri dari mahasiswi angkatan 2010 dan 2011 Fakultas Kedokteran Universitas Sam Ratulangi. Sampel didapatkan dari kejadian obes yang berjumlah 27 orang kemudian dan ditetapkan 22 orang yang memenuhi kriteria serta 22 orang non obes. Kriteria inklusi yaitu IMT $25-29,9 \mathrm{~kg} / \mathrm{m}^{2}$ pada obes dan IMT $18,5-22,9 \mathrm{~kg} / \mathrm{m}^{2}$ pada non obes, tidak merokok, tidak melakukan olahraga rutin. Kriteria eksklusi yaitu perokok. Alat yang digunakan dalam penentuan IMT yaitu dengan menggunakan timbangan berat badan dan pita pengukur tinggi (microtoise). Metode pemeriksaan sampel darah menggunakan ABX Pentra HDL Direct CP yaitu metode homogeny untuk pengukuran langsung kadar HDL-C dalam serum atau plasma tanpa menggunakan offline pretreatment. Pada penelitian ini analisis data yang digunakan yaitu Independent sample T test.

\section{HASIL}

\section{Karekteristik subjek penelitian}

Pada penelitian ini usia subjek penelitian yaitu 18-22 tahun, dimana umur yang terbanyak terdapat pada umur 20 tahun. Parameter yang diukur penelitian ini yaitu kadar kolesterol HDL darah pada wanita obes dan non obes dengan cara membandingkan hasil kadar kolesterol HDL darah tersebut berdasarkan pembagian Indeks Massa Tubuh (IMT). Kriteria yang diambil untuk memenuhi Indeks Massa Tubuh (IMT) pada responden obes berkisar antara 25-29,9 kg/m sedangkan kriteria untuk memenuhi responden non obes yaitu 18,5-22,9 kg/m². Untuk menentukan obes atau tidaknya seseorang digunakan rumus IMT terlebih dahulu. Selanjutnya untuk melihat tinggi 
rendahnya kadar kolesterol HDL darah pada masing-masing kelompok responden maka dikatakan tinggi apabila kadar kolesterol HDL darah $>60 \mathrm{mg} / \mathrm{dL}$ sebaliknya dikatakan rendah apabila kadar kolesterol HDL darah $<40$ mg/dL.

\section{Deskripsi karakteristik menurut usia}

Usia subjek penelitian yaitu wanita berumur antara 18 sampai 22 tahun. Distribusi subjek penelitian menurut usia terbanyak pada usia 20 tahun sebanyak 18 orang (40,9\%), usia 18 tahun sebanyak 6 orang $(13,6 \%)$, usia 21 tahun sebanyak 4 orang $(9,1 \%)$ dan terkecil pada usia 22 tahun dengan jumlah 1 orang (2,3\%).

\section{Berat badan dan tinggi badan subjek penelitian obes}

Distribusi subjek penelitian obes berdasarkan berat badan memiliki berat badan rata-rata $70,27 \mathrm{~kg}$, dengan berat maksimum $123 \mathrm{~kg}$ dan berat minimum 55 kg. Selanjutnya distribusi subjek penelitian obes berdasarkan tinggi badan memiliki rata-rata tinggi badan $1,57 \mathrm{~cm}$ dengan tinggi maksimum $1,65 \mathrm{~cm}$ dan tinggi minimum 1,48 cm.

\section{Berat badan dan tinggi badan subjek penelitian non-obes}

Distribusi subjek penelitian non obes berdasarkan berat badan memiliki rata-rata berat badan sebesar 50,77 $\mathrm{kg}$ dengan berat badan maksimum $64 \mathrm{~kg}$ dan berat badan minimum $44 \mathrm{~kg}$. Selanjutnya distribusi subjek penelitian non obes berdasarkan tinggi badan memilik rata-rata tinggi badan $1,57 \mathrm{~cm}$ dengan tinggi maksimum 1,76 cm serta tinggi minimum $1,49 \mathrm{~cm}$.

\section{Indeks massa tubuh (IMT)}

Rata-rata IMT subjek penelitian obes yaitu 28, dengan jumlah IMT maksimum 41 dan IMT minimum 25 sedangkan ratarata IMT subjek penelitian non obes yaitu 20,33, dengan jumlah IMT maksimum 23 dan IMT minimum 18.

\section{Kadar kolesterol HDL darah}

Berdasarkan distribusi kadar kolesterol HDL darah pada obes, maka subjek penelitian obes memiliki rata-rata kadar kolesterol HDL 57,64 mg/dL, dengan nilai maksimum $74 \mathrm{mg} / \mathrm{dL}$ dan nilai minimum 39 mg/dL. Sedangkan kadar kolesterol HDL darah pada non obes memiliki ratarata kadar kolesterol HDL 61,77 mg/dL, dengan nilai maksimum $103 \mathrm{mg} / \mathrm{dL}$ dan nilai minimum $36 \mathrm{mg} / \mathrm{dL}$.

Tabel 1. Distribusi perbandingan kadar kolesterol HDL darah obes dan non-obes.

\begin{tabular}{cccc}
\hline $\begin{array}{c}\text { Indeks } \\
\text { Masa } \\
\text { Tubuh }\end{array}$ & Jumlah & $\begin{array}{c}\text { Rata- } \\
\text { rata }\end{array}$ & $\begin{array}{c}\text { Standar } \\
\text { deviasi }\end{array}$ \\
\hline Obes & 22 & 57,64 & 11,189 \\
Non obes & 22 & 61,77 & 14,402 \\
\hline
\end{tabular}

\section{Uji persyaratan analisis}

Berdasarkan perhitungan menggunakan uji Shapiro-Wilk dari kadar kolesterol HDL darah pada normal dan obes, maka hasil yang didapatkan yaitu ,130. Suatu data yang dinyatakan berdistribusi normal jika probablitasnya lebih besar dari 0,05. Dari hasil yang didapatkan maka disimpulkan bahwa data berasal dari populasi yang berdistribusi normal.

\section{BAHASAN}

\section{Karakteristik subjek penelitian}

Usia dari kedua kelompok responden pada penelitian ini berkisar antara 18-20 tahun, dimana usia yang paling banyak yaitu pada usia 18 tahun sebesar 40,9\%. Distribusi berat badan pada kelompok obes yaitu rata-rata $70,27 \mathrm{~kg}$ dan tinggi badan rata-rata $1,57 \mathrm{~cm}$ sedangkan pada kelompok non obes memiliki rata-rata berat badan $50,77 \mathrm{~kg}$ serta tinggi badan $1,57 \mathrm{~cm}$. IMT rata-rata pada kelompok obes yaitu 28 $\mathrm{kg} / \mathrm{m}^{2}$ dan $20 \mathrm{~kg} / \mathrm{m}^{2}$ pada kelompok nonobes. 


\section{Kadar kolesterol HDL darah}

Kadar kolesterol HDL darah rata-rata pada orang normal berkisar antara 40-60 mg/dL. Menurut Levine (2006), kadar kolesterol HDL darah pada wanita lebih tinggi dibandingkan pria. Pada wanita kadar kolesterol HDL darah dikatakan normal apabila kadarnya $50-60 \mathrm{mg} / \mathrm{dL}^{8}{ }^{8}$ Penurunan kadar kolesterol HDL darah pada kelompok obes sama dengan penelitian yang dilakukan oleh Hudoglugil dkk (2005) yang menyatakan bahwa nilai IMT yang tinggi menunjukkan adanya hubungan dengan penurunan kadar kolesterol HDL darah ${ }^{9}$. Penelitian lain tentang terdapat hubungan antara obesitas dengan penurunan kadar kolesterol HDL serta peningkatan kadar kolesterol HDL juga dilakukan oleh Wira Goetara dkk (2006). ${ }^{10}$ Dengan meningkatnya kadar kolestreol LDL darah dan menurunnya kadar kolesterol HDL darah mempunyai pengaruh terhadap terjadinya penyakit jantung dan stroke. Berdasarkan data Riset Kesehatan Daerah (Riskesdas 2007), penyebab kematian semua umur di Indonesia adalah stroke $(15,4 \%)$, hipertensi (6,8\%), diabetes mellitus (5,7\%) dan penyakit jantung iskemik $(5,1 \%)^{11}$. Peningkatan kadar kolesterol HDL darah akan memperkecil rasio kolesterol total dan setiap penurunan satu unit rasio kolesterol total akan mengurangi risiko infark miokard sebesar $53 \%{ }^{12}$

Penelitian yang dilakukan di Framingham mendapatkan orang-orang dengan kadar kolesterol HDL darah yang rendah dan memiliki kadar trigliserida tinggi mempunyai angka risiko penyakit arteri koroner secara bermakna lebih tinggi dibandingkan orang-orang dengan kadar kolesterol HDL darah yang tinggi. ${ }^{13}$ Selain obesitas, beberapa hasil penelitian menunjukkan adanya faktor-faktor lain seperti aktifitas fisik, dan konsumsi serat yang mempengaruhi tinggi rendahnya kadar kolesterol HDL darah.

Manurung (2003) dalam penelitiannya mengatakan adanya aktifitas fisik atau olahraga dapat mempengaruhi peningkatan kadar kolesterol HDL darah, sama halnya dengan penilitian yang dilakukan oleh Raul (2009) dimana hasil penelitiannya tersebut mendapatkan aktifitas memiliki hubungan bermakna terhadap penurunan kadar kolesterol total dan peningkatan kadar kolesterol HDL darah. Sehingga jika berkurangnya aktifitas fisik maka akan berpengaruh terhadap penurunan kadar kolesterol HDL darah. $^{14,15}$ Namun, meskipun terjadi peningkatan berat badan, pada obesitas bisa terjadi peningkatan kadar kolesterol HDL darah jika orang dengan peningkatan berat badan tersebut mempunyai faktor-faktor lain yang meningkatkan kadar kolesterol HDL darah itu sendiri.

Faktor lain yang mempengaruhi adanya peningkatan kadar kolesterol HDL darah pada obesitas yaitu seperti apa yang telah dikatakan oleh Jorgensen dkk, dimana dia melakukan penelitian pada orang Inuit (Suku Eskimo) yang dengan IMT obes memiliki kadar kolesterol HDL darah cenderung tinggi dikarenakan pola hidup orang-orang tersebut mengkonsumsi tinggi daging ikan (pola konsumsi Greenlandic). Kandungan PUFA (Poly Unsaturated Fatty Acid) omega-3 dalam daging ikan tersebut akan mempengaruhi aktifitas metabolik pada jaringan adiposa sehingga menyebabkan peningkatan kadar koleserol HDL darah. ${ }^{16}$

Penelitian yang dilakukan oleh Hallfrich dkk menemukan adanya faktor lain yang menyebabkan peningkatan kadar kolesterol HDL yaitu dengan mengkonsumsi vitamin C. Konsumsi vitamin $\mathrm{C}$ dengan dosis optimal $345 \mathrm{mg} /$ hari juga dapat meningkatkan kadar kolesterol HDL darah jika kadar konsentrasi plasma vitamin C mencapai jumlah tertinggi.

Hasil analisis pada penelitian ini secara statistik tidak terdapat perbedaan yang bermakna antara kadar kolesterol HDL darah pada obes dan non obes, tetapi terdapat perbedaan sebesar $4,1 \mathrm{mg} / \mathrm{dL}$ atau $6,7 \%$ dari rata-rata $57,64 \mathrm{mg} / \mathrm{dL}$ pada obes serta $61,77 \mathrm{mg} / \mathrm{dL}$ pada non obes.

\section{SIMPULAN}

Secara statistik tidak ditetapkan bahwa terdapat perbedaan yang bermakna antara 
kadar kolesterol HDL darah pada obes dan non obes.

\section{DAFTAR PUSTAKA}

1. Botham KM, Mayes PA. Pengangkutan dan Penyimpanan Lipid. Dalam: Murray RK, Granner DK, Rodwell VW, editor. Biokimia Harper (Edisi Keduapuluh Tujuh). Alih Bahasa: Pendit B. Jakarta: EGC, 2006; h.225-38.

2. Ashen MD, Blumenthal RS. Low HDL Cholesterol Levels. N Engl J Med. 2005; 353:1252-1260.

3. Soeharto I. Penyakit Jantung Koroner dan Serangan Jantung Edisi Kedua. Jakarta : PT Gramedia Pustaka Utama, 2004; h.110-1.

4. Guyton AC, Hall JE. Keseimbangan Diet; Aturan Pemberian Makanan; Obesitas dan Kelaparan; Vitamin dan Mineral. Dalam: Rachman LY, Hartanto H, Novrianti A, Wulandari N, editor. Buku Ajar Fisiologi Kedokteran (Edisi Kesebelas). Jakarta: EGC, 2007; h.917.

5. Soegondo S, Purnamasari D. Sindrom Metabolik. Dalam: Sudoyo AW, Setiyohadi B, Alwi I, Simadibrata M, Setiadi S, editor. Ilmu Penyakit Dalam Jilid III (Edisi Kelima). Jakarta: Pusat Penerbitan Ilmu Penyakit Dalam Fakultas Kedokteran Universitas Indonesia, 2009; h.1865.

6. Apa Itu Obesitas [homepage on the Internet]. Nodate [cited 2012 Sept 29]. Available from: http://www.news-medical.net/ health/what-is-obesity-(indonesian). aspx.

7. Pengidap Obesitas Akibat Gaya Hidup Makin Bertambah [homepage on the Internet]. c2012 [cited 2012 Nov 06]. Available from: http://manado.tribun news.com/2012/07/13/pengidapobesitas-akibat-gaya-hidup-makinbertambah (RISKESDAS).
8. Levine TB, Levine AB. Manifestation of Insulin Resistance. Pioli S, editor. Metabolic Syndrome and Cardiovascular Disease. United States of America, 2006; p.238.

9. Hodoglogil $\mathbf{U}$, et al. An interaction between the TaqIB polymorphism of cholesterol ester transfer protein and smoking in associated with changes in plasma highdensity lipoprotein cholesterol levels in Turks. Clin. Genet 2005;68:118-27.

10. Gotera W, Aryana S, Suastika K, Santoso A, Kuswardhani, T. Hubungan antara obesitas sentral dengan adiponektin pada pasien geriatri dengan penyakit jantung koroner. Denpasar: FK Unud/RSUP Sanglah; 2006.

11. Departemen Kesehatan. Riset Kesehatan Dasar Indonesia 2007. Jakarta: Badan Litbang Kesehatan; 2008.

12. Griel AE, Kris Etherton PM. Beyon Saturated fat: the importance of the dietary fatty acid profile on cardiovascular disease. Nutr. Rev. 2006;64(5):257-62.

13. Gordon, et al. High density lipoprotein sebagai faktor protektif terhadap penyakit jantung koroner: Studi Framingham. American Journal of Medicine 1977;62:707-4.

14. Mamat, Sudikno. Faktor-faktor yang berhubungan dengan kadar kolesterol HDL. Gizi Indon. 2010;33(2):143-9

15. Raul. Low and High Density Lipoprotein Cholesterol Goald Attainment in Dyslipidemic Women. American Heart Journal. 2009;158(5):860-6.

16. Marit E Jorgensen, Knut Borch-Johnsen, and Peter Bjerregaard. Lifestyle modified obesity-associated risk of cardiovascular disease in a genetically homogenous population. Am J Clin Nutr. 2006:29-36. 